Estimates of the Potential

Petroleum Resources in

Wilderness Lands

By Betty M. Miller

PETROLEUM POTENTIAL OF WILDERNESS LANDS IN THE WESTERN UNITED STATES

GEOLOGICAL SURVEY CIRCULAR 902-P 



\section{CONTENTS}

Abstract
Introduction-
Results of qualitative petroleum analysis
Petroleum potential maps-
Results of quantitative petroleum analysis
Summary -1
Reference cited

\section{ILLUSTRATIONS}

FIGURE 1. Index map of Wilderness Lands study area listing identification for USGS Miscellaneous Investigations Series Maps to be published showing petroleum potential for Wilderness Lands at a scale of 1:1,000,000 _-____ P4

2-12. Undiscovered recoverable [oil and gas] resources in Wilderness Lands in:

2. Arizona

3. California

4. Colorado

5. Idaho

6. Montana

7. Nevada-

8. New Mexico

9. Oregon

10. Utah

11. Washington

12. Wyoming

13. Total undiscovered recoverable [oil and gas] resources in Wilderness Lands in 11 Western States

14. Total undiscovered recoverable [ oil and gas] resources in the 38 USGS petroleum provinces in which Wilderness

Lands are located that were included in this study

\section{TABLES}

TABLE 1. Petroleum potential by acreage for all Wilderness Land categories in the Western United States

2. Petroleum potential by acreage for all Wilderness Lands in the Western United States by controlling Federal agency -

3. Petroleum potential in Wilderness Lands by State in Western United States

4. Statistics on the distribution of Wilderness Lands in the Western United States- 


\title{
PETROLEUM POTENTIAL OF WILDERNESS LANDS IN THE WESTERN UNITED STATES
}

\author{
Estimates of the Potential Petroleum Resources \\ in Wilderness Lands
}

By Betty M. Miller

\begin{abstract}
The estimates of the potential petroleum resources for the Wilderness Lands in the 11 Western States were conducted in two distinct and separate phases for this study: the qualitative analysis and the quantitative analysis. The analysis of the geologic characteristics favorable or unfavorable for the occurrence of recoverable oil and gas resources for all the Wilderness Lands provided the input used by the geologists to subiectively determine the qualitative estimates of the petroleum resources for each tract and also provided the basic input for the subjective estimates for the quantitative analysis.

A gradational rating scale was assigned by the geologists to each wilderness tract and included the following categories of potential: high, medium, low, low to zero, zero, and unknown. A summary of the total wilderness acreages compiled according to their respective estimated petroleum potentials shows: at least 34 percent of the total 74 million acres of Wilderness Lands have the geologic characteristics necessary for the occurrence of petroleum resources in varying amounts (high, medium, and low); an additional 33 percent of the Wilderness Lands may have some small potential, but is more likely to fall in the low to zero potential and the unknown categories; and 33 percent of the total acreage of the Wilderness Lands probably has no petroleum potential because it is located in predominately igneous and (or) metamorphic terrane.

The qualitative petroleum potential for all the Wilderness Lands is also being published as color-coded maps in the USGS
\end{abstract}

Miscellaneous Investigations Series Maps (I-1537 through I1547 , in press) for each of the Western States at a scale of $1: 1,000,000$.

The quantitative resource estimates for oil and natural gas for the Wilderness Lands are expressed as probability distributions for the individual States and aggregated totals for the 11 Western States. The total undiscovered recoverable oil for the Wilderness Lands in the Western States is estimated to range from more than 0.555 to 1.490 billion barrels with a mean estimate of 0.834 billion barrels. The undiscovered recoverable natural gas is estimated to range from more than $\mathbf{5 . 5 3 6}$ to 16.639 trillion cubic feet with a mean estimate of 9.729 trillion cubic feet. The ranges are reported at the 95 and 5 percent probability levels.

\section{INTRODUCTION}

The petroleum resource assessments for the Wilderness Lands in the 11 Western States were conducted in two distinct and separate phases for this study. These two phases are referred to as the qualitative analysis and the quantitative analysis of the potential petroleum resources. The products and results of these two analyses are discussed separately below. 


\section{RESULTS OF QUALITATIVE PETROLEUM ANALYSIS}

The geologic analysis for characteristics favorable or unfavorable for the occurrence of recoverable oil and gas resources for all the Wilderness Lands provided the input used by the geologists to subjectively determine the qualitative estimates of the petroleum resources for each tract. Using a simplification of the gradational rating scale, the geologists assigned one of six classes (high, medium, low, low to zero, zero, and unknown) to designate the probable petroleum potential in each tract. The potential petroleum resource categories can be tabulated by the total acreages for each wilderness tract. These tabulations are made for the Wilderness Lands by petroleum province, by State, and for the total Wilderness Lands in the 11 Western States. Table 1 shows a summary by State of the total wilderness acreages compiled according to their respective estimated petroleum potentials by category-ratings and the total acreages for each petroleum potential category for the 11 States.

A simplification of the figures shown in table 1 is summarized in the following manner relative to the geologic favorability for potential petroleum resources:
High potential.-Approximately 4 percent of the total acreage in Wilderness Lands in the Western United States has a high potential.

Medium potential.-At least 8 percent of the total acreage in Wilderness Lands has a medium or possibly higher potential.

Low potential.-Nearly 22 percent of the total acreage in Wilderness Lands has potential for petroleum resources; these areas are classified with at least a low potential until more is known about the geology.

Low to zero potential.-At least 28 percent of the total acreage of the Wilderness Lands consists of small sedimentary areas mixed within igneous and metamorphic terrane that may have some small and scattered potential but most likely a very low to zero overall petroleum potential.

Zero potential.-Thirty-three percent of the total acreage of the Wilderness Lands occur in igneous and metamorphic terranes that probably have no potential for petroleum occurrence.

Unknown potential.-In almost 5 percent of the total acreage of the Wilderness Lands not enough is known of the subsurface geology to make any iudgment on the favorability of the lands for petroleum potential.

At least 34 percent of the total acreage for Wilderness Lands, or approximately 25 million acres,

TABLE 1.-Petroleum potential ${ }^{1}$ by acreage for all Wilderness Land categories ${ }^{2}$ in the Western United States

\begin{tabular}{|c|c|c|c|c|c|c|c|}
\hline \multirow{2}{*}{ State } & \multicolumn{6}{|c|}{ Petroleum potential in thousands of acres } & \multirow{2}{*}{ Total } \\
\hline & High & Medium & Low & Low-Zero & Zero & Unknown $^{3}$ & \\
\hline Arizona & 0 & 192.0 & $1,375.3$ & $3,528.8$ & $1,087.8$ & 0 & $6,183.8$ \\
\hline California & 0 & 36.5 & $1,310.2$ & $10,249.3$ & $7,252.6$ & 0 & $18,848.6$ \\
\hline Colorado & 140.2 & 94.8 & 819.4 & $\mathbf{0}$ & $2,445.3$ & $1,001.4$ & $4,501.1$ \\
\hline İdaho & 115.1 & 63.4 & 804.7 & $1,023.7$ & $5,515.6$ & 36.7 & $7,559.2$ \\
\hline Montana & $1,374.2$ & $1,154.8$ & $1,325.9$ & $1,212.2$ & $1,825.4$ & 38.2 & $6,930.7$ \\
\hline Nevada & 132.4 & $1,099.1$ & $3,631.2$ & 0 & $3,117.9$ & 0 & $7,980.6$ \\
\hline New Mexico & 96.6 & 115.3 & $1,237.3$ & 158.0 & $1,069.6$ & 0 & $2,676.8$ \\
\hline Oregon & 0 & 138.2 & $2,869.7$ & $1,857.9$ & 0 & 0 & $4,865.8$ \\
\hline Utah & 208.9 & $2,638.3$ & $1,010.4$ & 0 & 625.2 & 0 & $4,482.8$ \\
\hline Washington & 0 & 0 & 952.4 & $2,940.5$ & 0 & 0 & $3,892.9$ \\
\hline Wyoming & 661.8 & 391.8 & 723.3 & 19.0 & $1,759.3$ & $2,451.8$ & $6,007.0$ \\
\hline Total & $2,729.2$ & $5,924.2$ & $16,059.7$ & $20,989.4$ & $24,698.7$ & $3,528.1$ & $73,928.3$ \\
\hline
\end{tabular}

'Petroleum potential: The geologists evaluated the geological characteristics for the favorability of the occurrence of oil and natural gas and assigned a qualitative rating for the potential for petroleum resources, such as high, medium, etc.

'The Wilderness Lands included in this study are identified under the following categories: Designated Wilderness, Administratively Endorsed as Suitable (prior to July 1981), Further Planning or Study Areas, BLM Lands Under Appeal, BLM Wilderness Inventory Not Completed, and U.S. Forest Service RARE II under litigation in California. These lands are administered under four agencies: Bureau of Land Management (BLM), U.S. Forest Service (USFS), National Park Service (NPS), and Fish and Wildlife Service (FWS).

'Unknown Potential: The rating of unknown is used in some wilderness areas where the geology is almost completely unknown or not enough information is available currently for the geologist to make any judgment on the favorability of the area for petroleum potential.

'Total acreage for Wilderness Lands is the same as in table 2. All tabulated values are rounded numbers; therefore values may not be precise beyond decimal. 
may have the geologic characteristics necessary for the occurrence of petroleum resources in varying amounts (high, medium, and low potential). An additional 33 percent of the total acreage of the Wilderness Lands may have some small potential, but is more likely to fall in the low to zero potential and in the unknown categories. Finally, 33 percent of the total acreage of the Wilderness Lands probably has no petroleum potential because the lands are located in terranes with predominantly igneous and (or) metamorphic rocks in which petroleum has rarely been found. The total acreage analyzed in this study for the 11 Western States is 74 million acres.

Table 2 shows a summary of the petroleum potential by acreage for all the Wilderness Land categories in the Western United States by the controlling Federal agency. The amounts of the Wilderness Lands in this study administered by the four agencies are as follows:

Bureau of Land Management: 37 percent, nearly 27 million acres;

Forest Service: 45 percent, nearly 34 million acres;

National Park Service: 14 percent, nearly 10 million acres;

Fish and Wildlife Service: 4 percent, 3 million acres.

Over 20 million acres that may have the geologic characteristics necessary for the occurrence of petroleum resources in varying amounts (high, medium, and low) are administered by the Bureau of Land Management (12.6 million acres) and the Forest Service (7.7 million acres). The remaining potential 4.5 million acres of the total 25 million as discussed in table 1 are administered by the National Park Service and the Fish and
Wildlife Service. The Forest Service has the largest amounts of Wilderness Lands with zero petroleum potential (16.8 million acres), with the Bureau of Land Management second, having 4.9 million acres of Wilderness Lands with zero petroleum potential, due primarily to locations within terranes with predominantly igneous and (or) metamorphic rocks. Mineral resource assessments were not included in this study.

\section{PETROLEUM POTENTIAL MAPS}

The qualitative ratings for petroleum potential were numerically encoded, and through application of digital cartographic techniques were used to generate machine-plotted, color-coded maps of the petroleum potential in the Wilderness tracts in each of the 11 States at a scale of 1:1,000,000.

A complete set of maps, one for each of the 11 States is being published by the USGS as Miscellaneous Investigations Series Maps (I-1537 through I-1547, in press; see fig. 1) that shows in color the locations and boundaries of the designated and proposed Wilderness Lands in the State with official identifications, and the potential for petroleum occurrence for each Wilderness tract that is dependent upon the known geologic characteristics in the area. In addition, the boundary locations are shown for all other Federal lands and Indian lands, along with the geographic, drainage, and cultural data, latitude and longitude coordinates, and the locations and identification of the USGS petroleum province boundaries. The Iseries maps are published at a scale of $1: 1,000,000$ and are being prepared and documented to accompany this report. Additional information on the preparation of these maps is discussed by $M$. A. Domaratz and J. A. Stapleton in chapter B in this circular on digital cartography.

TABLE 2.-Petroleum potential by acreage for all Wilderness Lands in the Western United States by controlling Federal agency

\begin{tabular}{lrrrrrrr}
\hline & \multicolumn{6}{c}{ Petroleum potential in thousands of acres } \\
\cline { 2 - 7 } \multicolumn{1}{c}{ Federal agency } & High & Medium & Low & Low-Zero & Zero & Unknown & Total \\
\hline & & & & & & \\
Bureau of Land Management & $1,039.7$ & $3,562.0$ & $7,954.7$ & $9,401.6$ & $4,926.6$ & 111.6 & $26,996.2$ \\
Forest Service & $1,114.6$ & $1,275.3$ & $5,317.3$ & $7,509.6$ & $16,750.3$ & $1,751.3$ & $33,718.4$ \\
National Park Service & 563.4 & 916.5 & $1,327.5$ & $2,937.3$ & $2,713.5$ & $1,665.1$ & $10,123.3$ \\
Fish and Wildlife Service & 11.5 & 170.3 & $1,460.0$ & $1,140.7$ & 308.2 & 0 & $3,090.7$ \\
Total & $2,729.2$ & $5,924.1$ & $16,059.5$ & $20,989.2$ & $24,698.6$ & $3,528.0$ & $73,928.6^{1}$ \\
\hline
\end{tabular}

'Total acreage for all Wilderness Lands is the same as in table 1. All tabulated values are rounded numbers; therefore values may not be precise beyond decimal. 


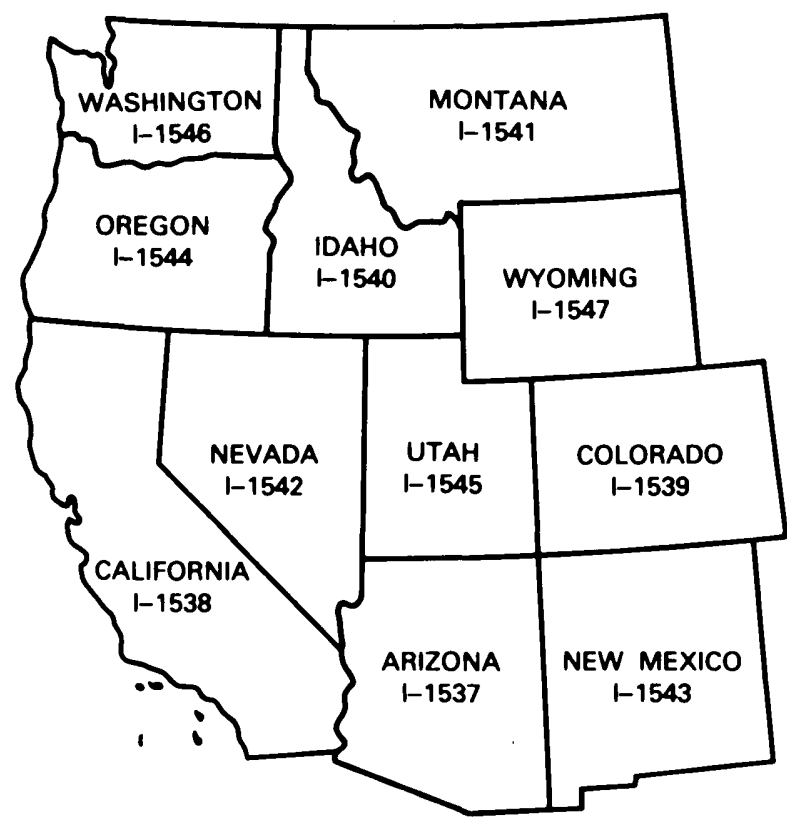

Figure 1.-Index map of Wilderness Lands study area listing identification for USGS Miscellaneous Investigations Series Maps I-1537 through I-1547 to be published showing petroleum potential for Wilderness Lands at a scale of $1: 1,000,000$.

\section{RESULTS OF QUANTITATIVE PETROLEUM ANALYSIS}

The quantitative petroleum resource analysis for the Wilderness clusters for each of the 11 Western States represents a part of the total estimate of the remaining undiscovered oil and natural gas resources as reported by Dolton and others (1981) in Circular 860 for the respective province within which the Wilderness Lands occur. Wilderness Lands within the Western States are located within 38 of the USGS petroleum provinces defined by Dolton and others (1981) (see appendix). The major portions of four of these provinces fall outside the eastern limit of the study area. They are the Williston basin, Denver basin, Palo Duro basin, and the Permian basin.

The estimates for the individual wilderness clusters are weighted in respect to their geologic characteristics that make them favorable or unfavorable for the occurrence of petroleum. This is calculated by applying the minimum and maximum range of richness factors $(r)$ for each cluster. In addition, the estimates take into account the marginal probability assigned for recoverable resource being present within each wilderness cluster. See chapter $O$ in this circular by $R$. A. Crovelli on statistical methodology for a detailed explanation of the mathematical procedures.
The quantitative assessments are expressed as probability distributions for oil and for natural gas. Although it may be convenient to use a point estimate, such as the mean as a basis for comparison, a range of values more properly expresses the uncertainty inherent in estimates of undiscovered resources. Probability distributions for the undiscovered recoverable oil and natural gas for the individual wilderness clusters (or tracts) are aggregated by a Monte Carlo technique for each of the States and for totals for the 11 States. The undiscovered oil and natural gas (unconditional or risked assessments) for the individual States are presented in figures 2 through 12 and show the amounts of resources and the respective probabilities of more than those amounts. Figure 13 shows the total amounts of undiscovered oil and natural gas for all the Wilderness Lands in the Western United States.

The undiscovered recoverable oil for the Wilderness Lands in the 11 Western States is estimated to range from more than 0.555 to 1.490 billion barrels with a mean estimate of 0.834 billion barrels. The undiscovered recoverable natural gas is estimated to range from more than 5.536 to 16.639 trillion cubic feet with a mean estimate of 9.729 trillion cubic feet. Each range corresponds to the 95 percent and 5 percent probabilities of more than the respective amounts. These estimates are reported at the 95 percent and 5 percent probabilities and the mean, median, and mode estimates and the standard deviation (S.D.) for oil and for natural gas and are summarized in table 3 for the separate States and the aggregated totals.

For comparative purposes the total undiscovered recoverable oil and natural gas resources for the 38 petroleum provinces, as assessed by Dolton and others (1981), were aggregated to provide probability distributions for the total resource amounts for those provinces in which the Wilderness Lands are located in this study. These distributions are presented in figure 14. An estimated percentage range of the amounts of petroleum resources within these 38 provinces which may occur within the designated and proposed Wilderness Lands for the 11 Western States is as follows:

Undiscovered recoverable oil: 2.2 percent to 3.3 percent of the total oil resource at the 95 and 5 percent probability range.

Undiscovered recoverable gas: 3.9 percent to 6.5 percent of the total natural gas resource at the 95 and 5 percent probability range. 
OIL - ARIZONA

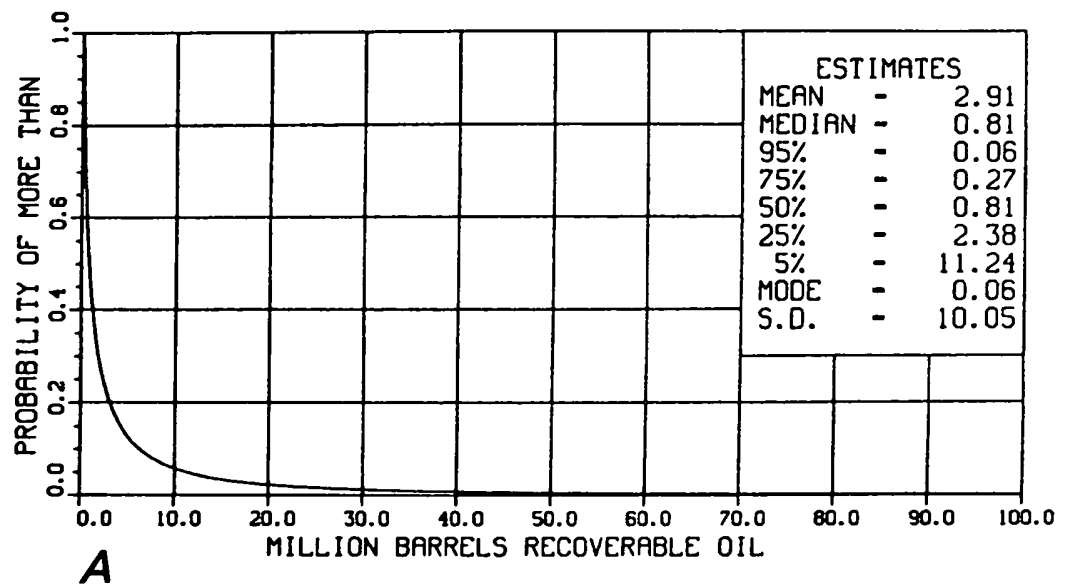

FIGURE 2A.-Undiscovered recoverable oil resources in Wilderness Lands in Arizona.

\section{뭉}

OIL - CALIFORNIA

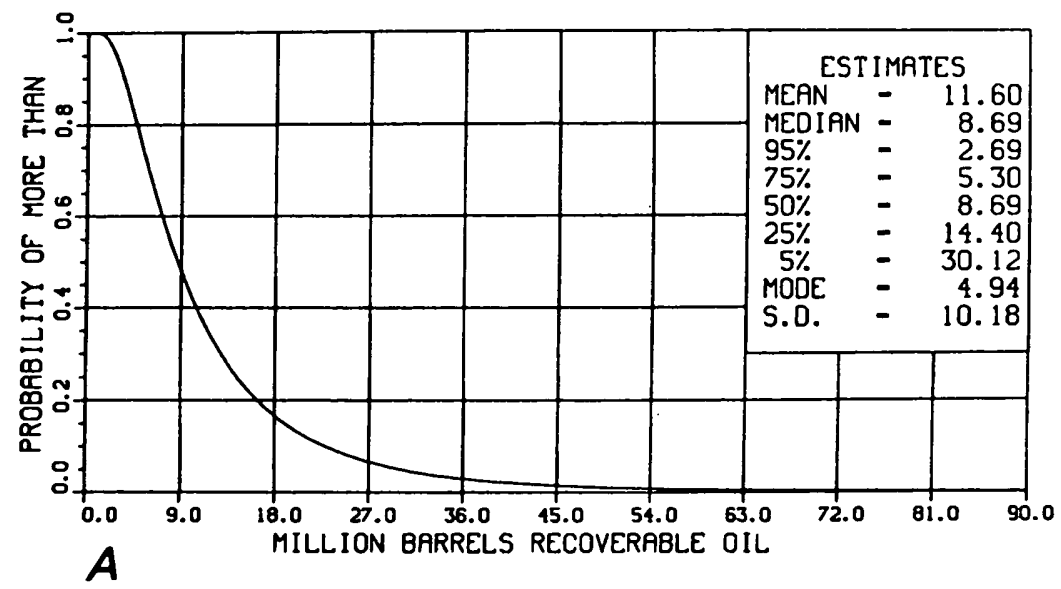

Figure 3A.-Undiscovered recoverable oil resources in Wilderness Lands in California.

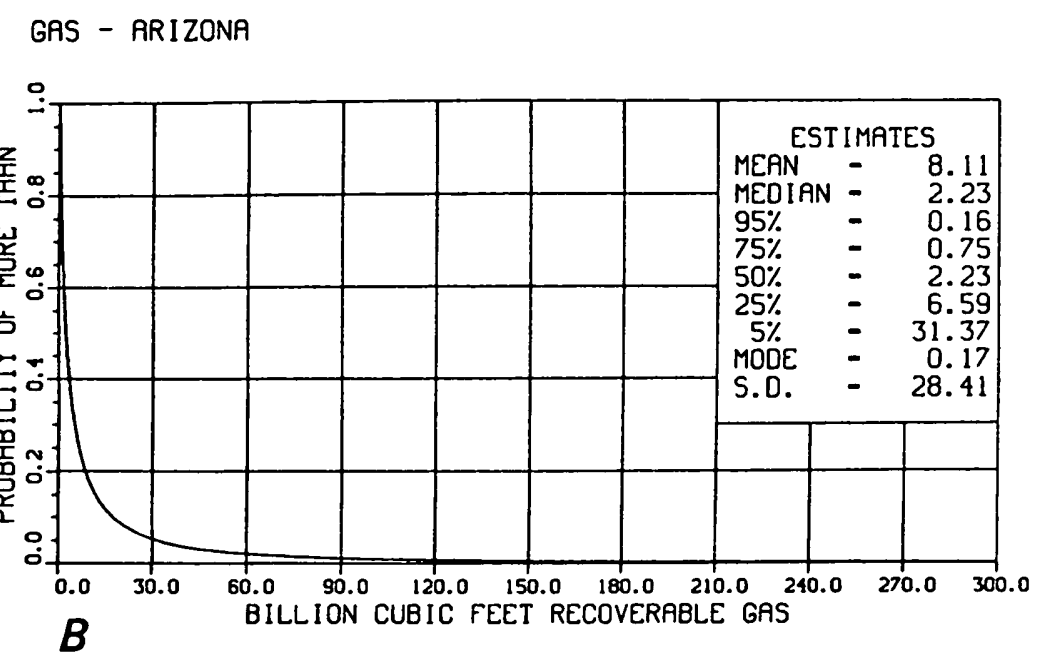

Figure 2B.-Undiscovered recoverable gas resources in Wilderness Lands in Arizona.

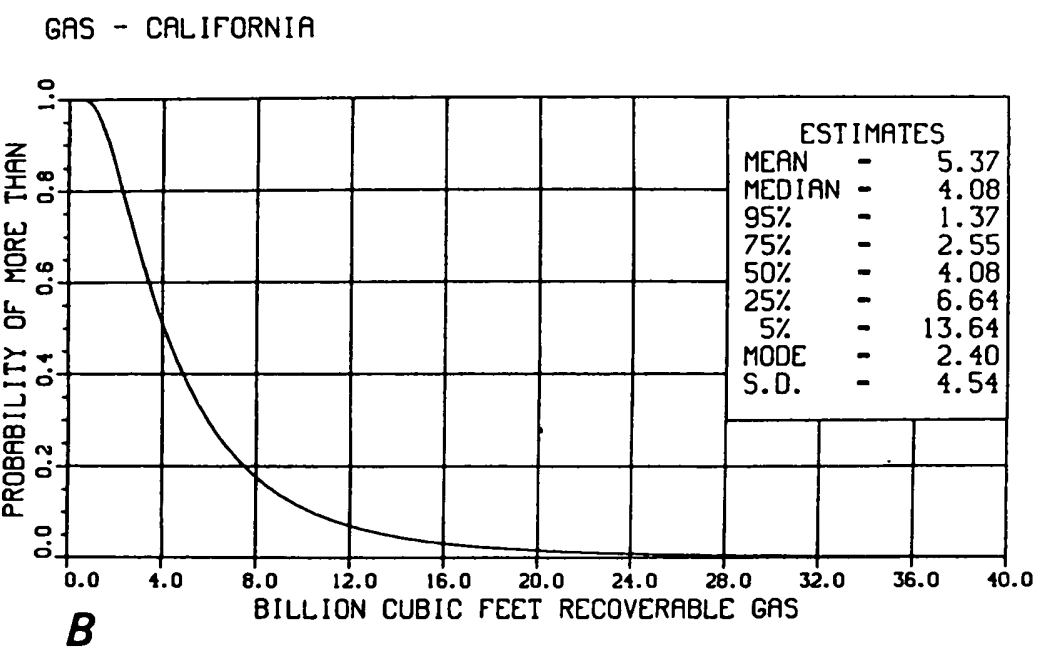

FiguRE 3B.-Undiscovered recoverable gas resources in Wilderness Lands in California. 


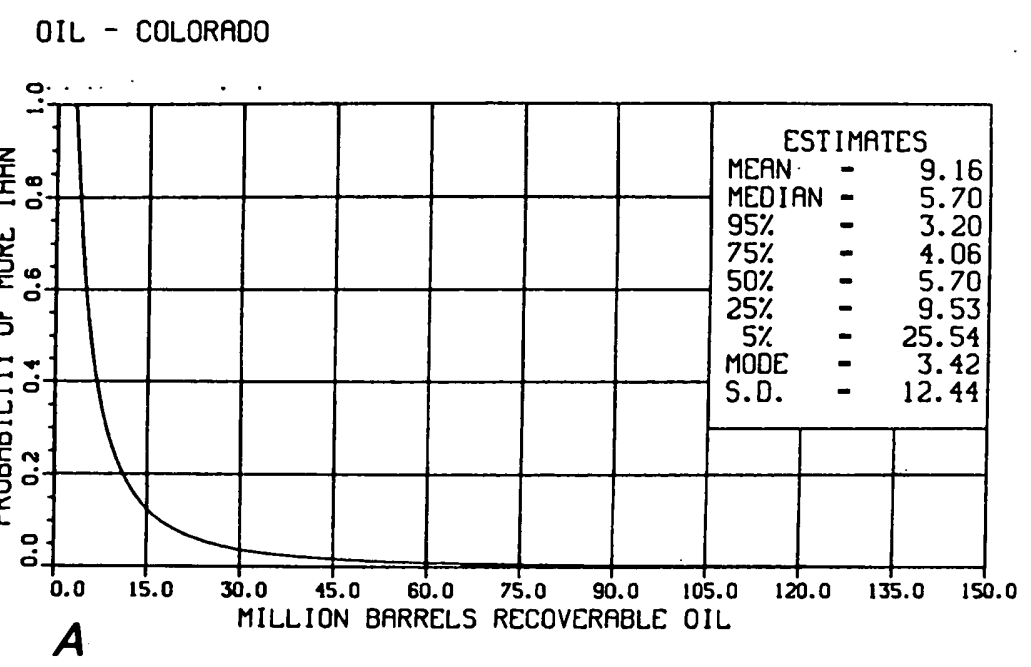

FiguRE 4A.-Undiscovered recoverable oil resources in Wilderness Lands in Colorado.

o

$$
\text { OIL - IORHO }
$$

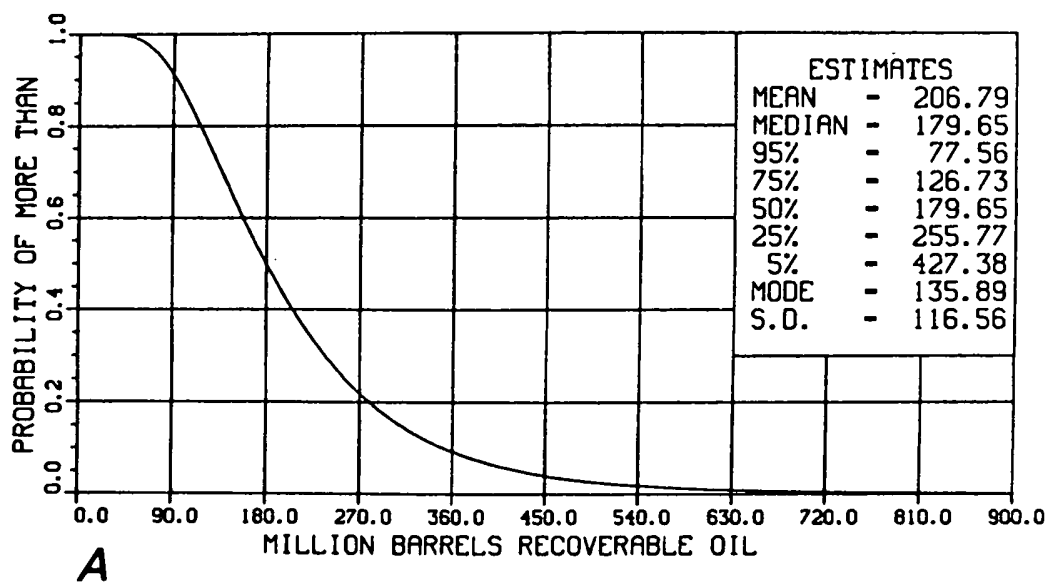

FIGURE 5A.-Undiscovered recoverable oil resources in Wilderness Lands in Idaho.
GAS - COLORADO

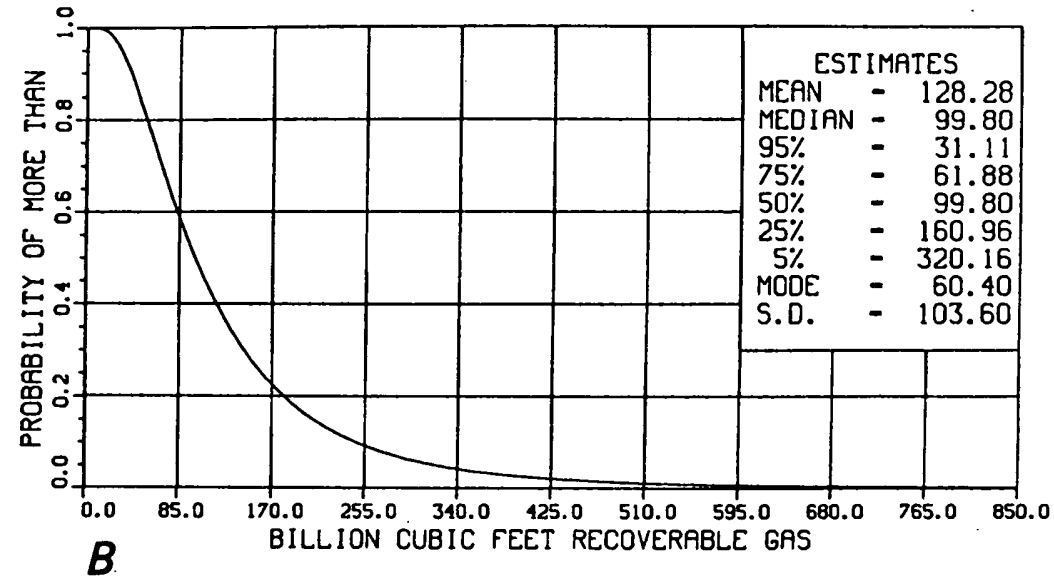

Figure 4B.-Undiscovered recoverable gas resources in Wilderness Lands in Colorado.

GAS - IDAHO

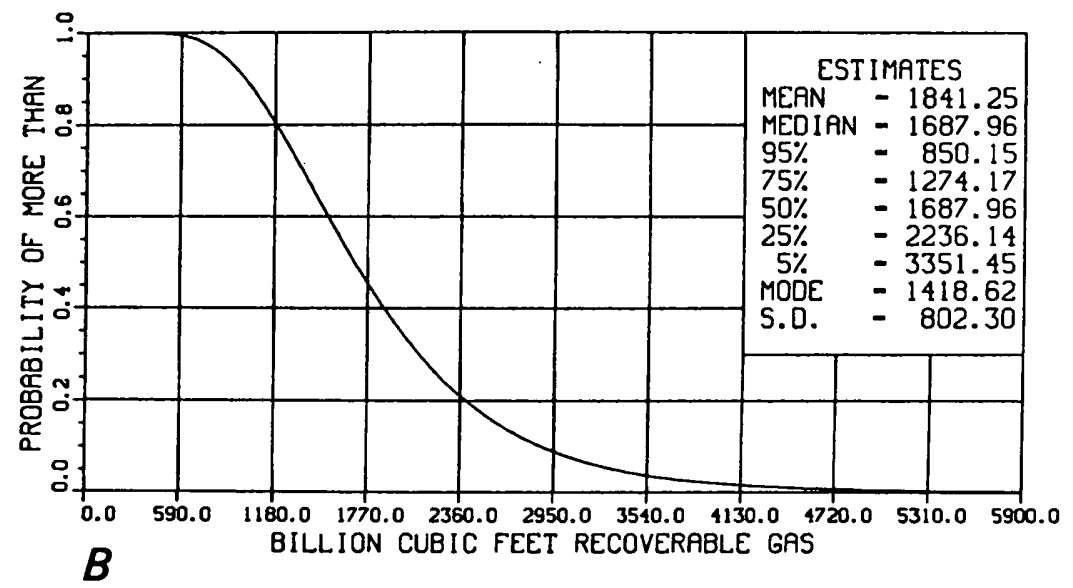

Figure 5B.-Undiscovered recoverable gas resources in Wilderness Lands in Idaho. 
OIL - MONTANA

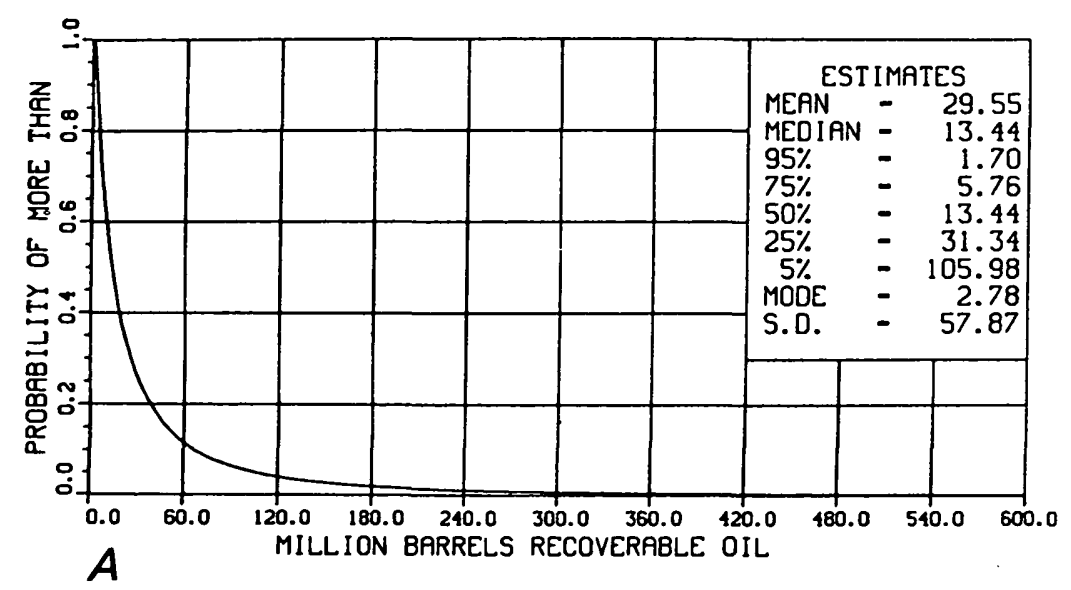

Figure 6A.-Undiscovered recoverable oil resources in Wilderness Lands in Montana.

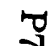

$$
\text { OIL - NEVADR }
$$

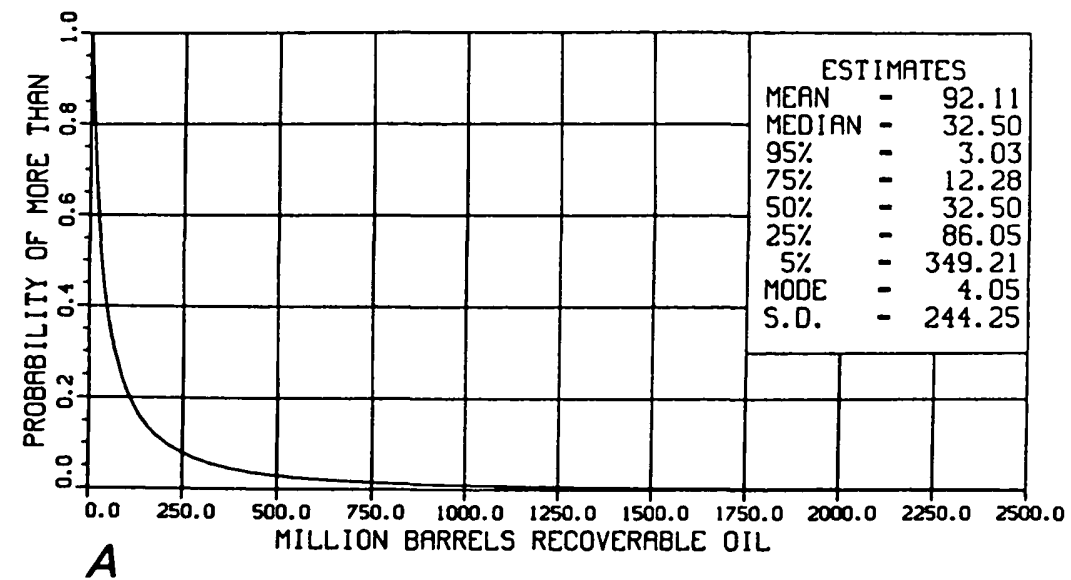

Figure 7A.-Undiscovered recoverable oil resources in Wilderness Lands in Nevada.
GAS - MONTANA

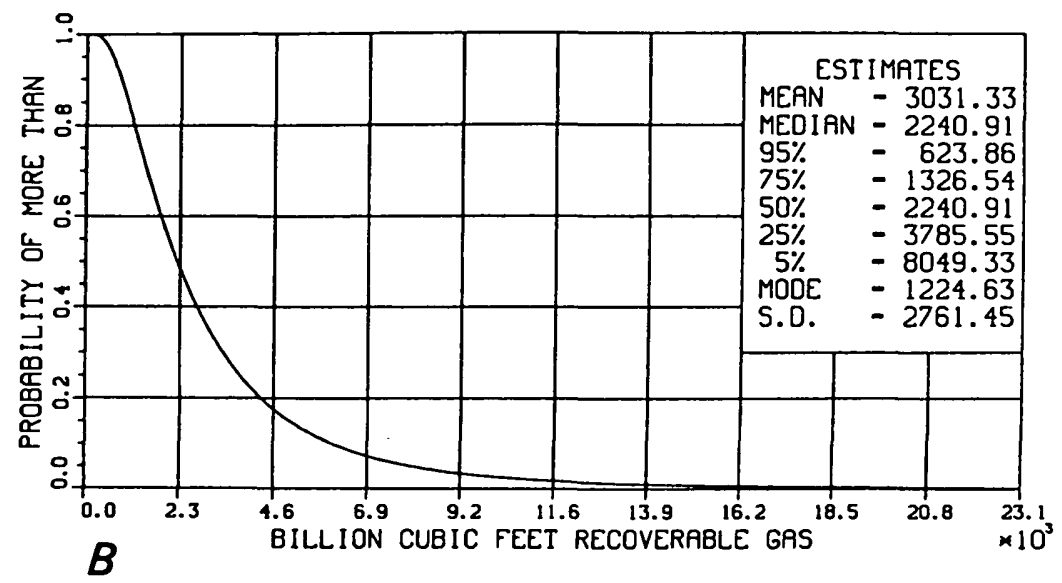

FIGURE 6B.-Undiscovered recoverable gas resources in Wilderness Lands in Montana.

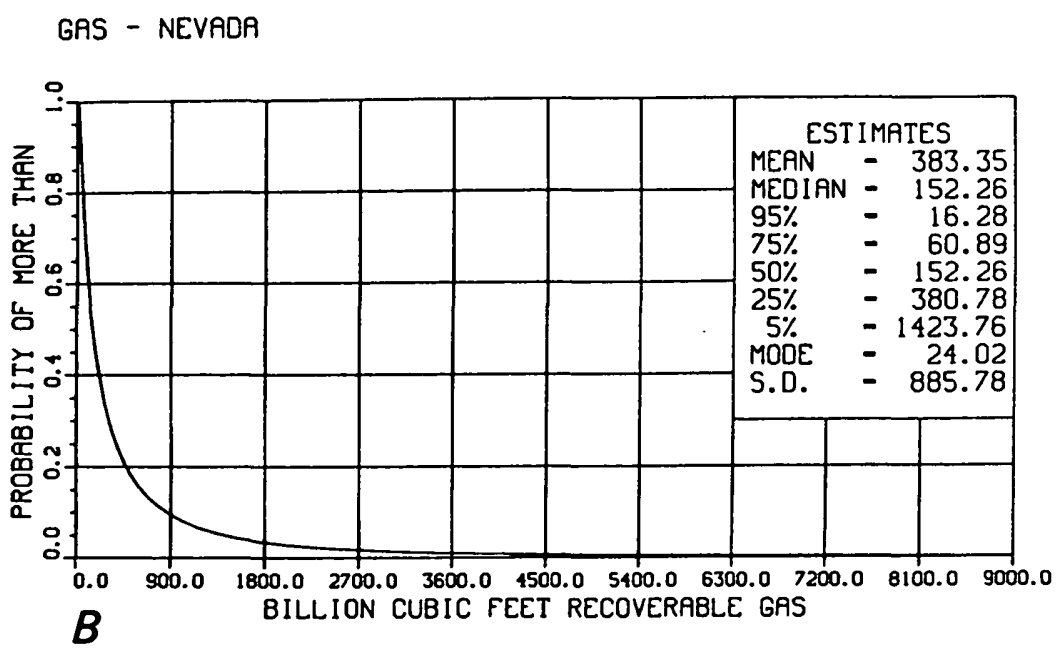

Figure $7 B$.- Undiscovered recoverable gas resources in Wilderness Lands in Nevada. 
OIL - NEW MEXICO

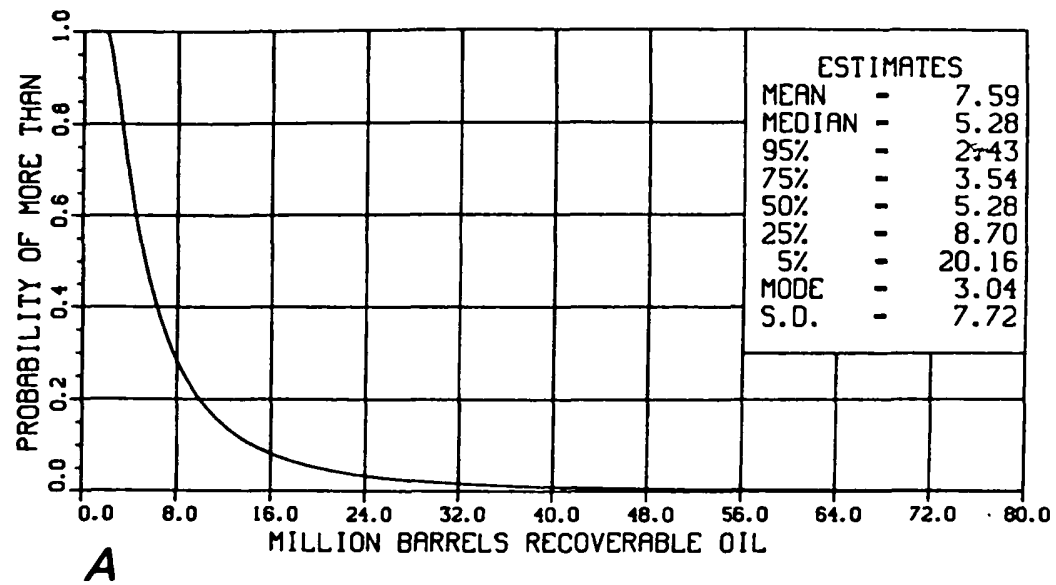

FIGURE $8 A$.-Undiscovered recoverable oil resources in Wilderness Lands in New Mexico.

$\infty$

OIL - OREGON

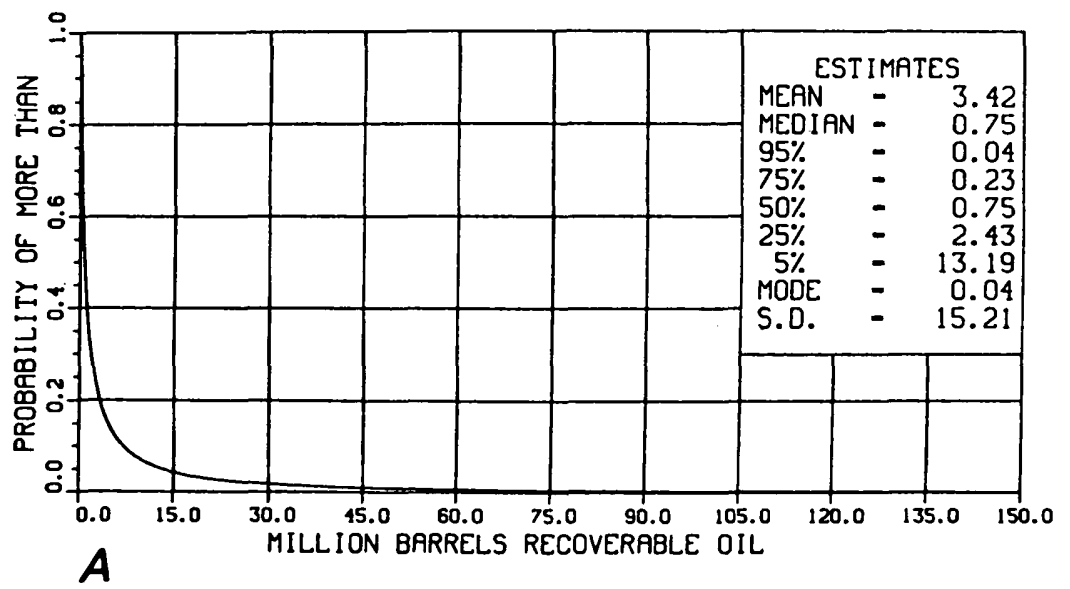

Figure 9A.-Undiscovered recoverable oil resources in Wilderness Lands in Oregon.
GAS - NEW MEXICO

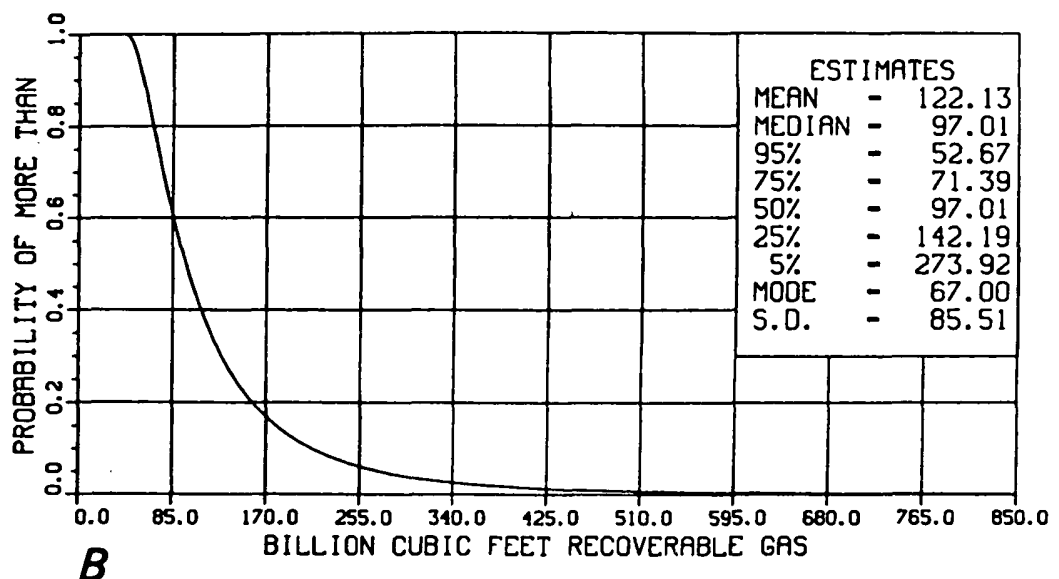

Figure 8B.-Undiscovered recoverable gas resources in Wilderness Lands in New Mexico.

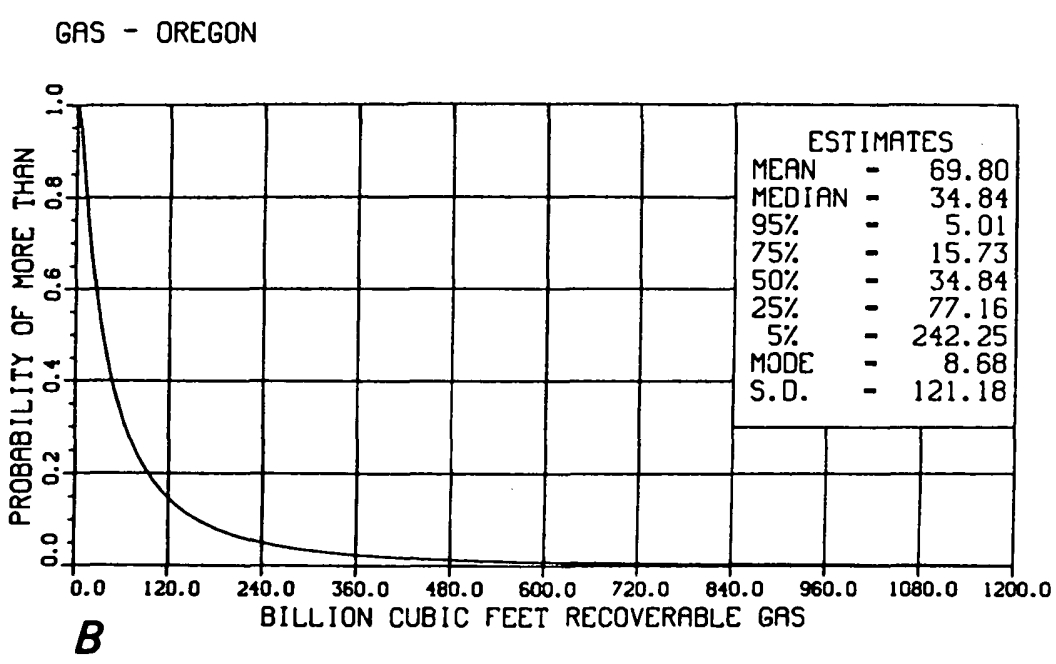

FIgURE 9B.-Undiscovered recoverable gas resources in Wilderness Lands in Oregon. 
OIL - UTAH

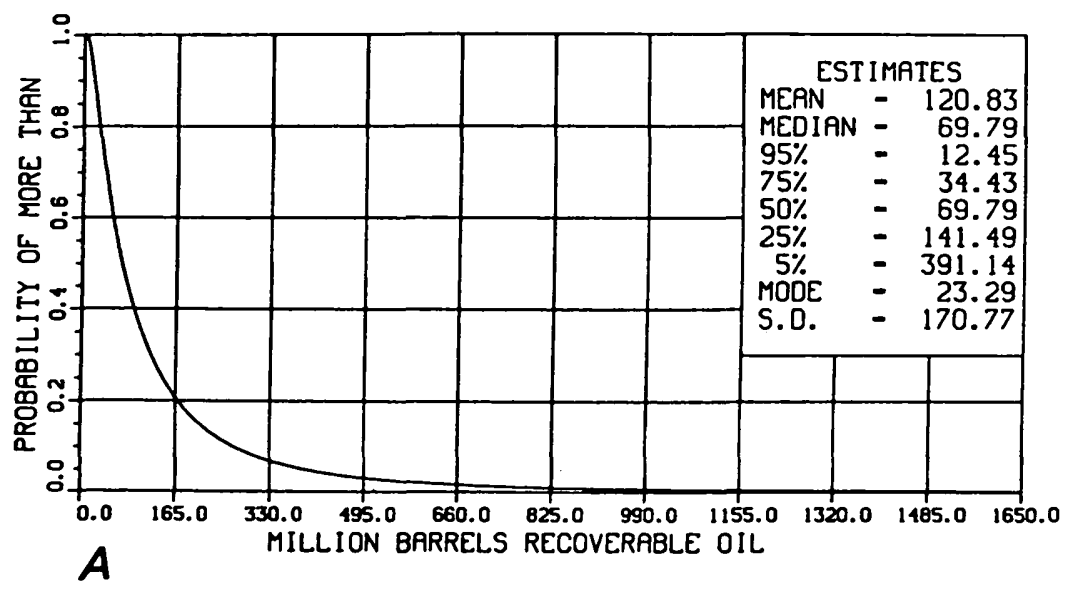

FIGURE 10A.-Undiscovered recoverable oil resources in Wilderness Lands in Utah.

7ृำ

\section{OIL - WASHINGTON}

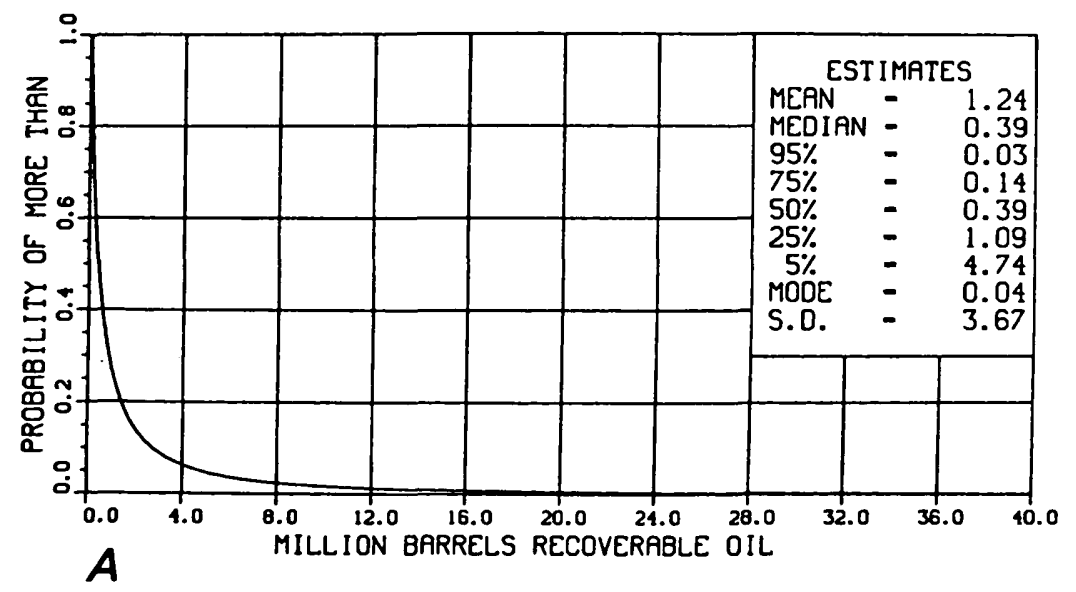

FIGURE 11A.-Undiscovered recoverable oil resources in Wilderness Lands in Washington.

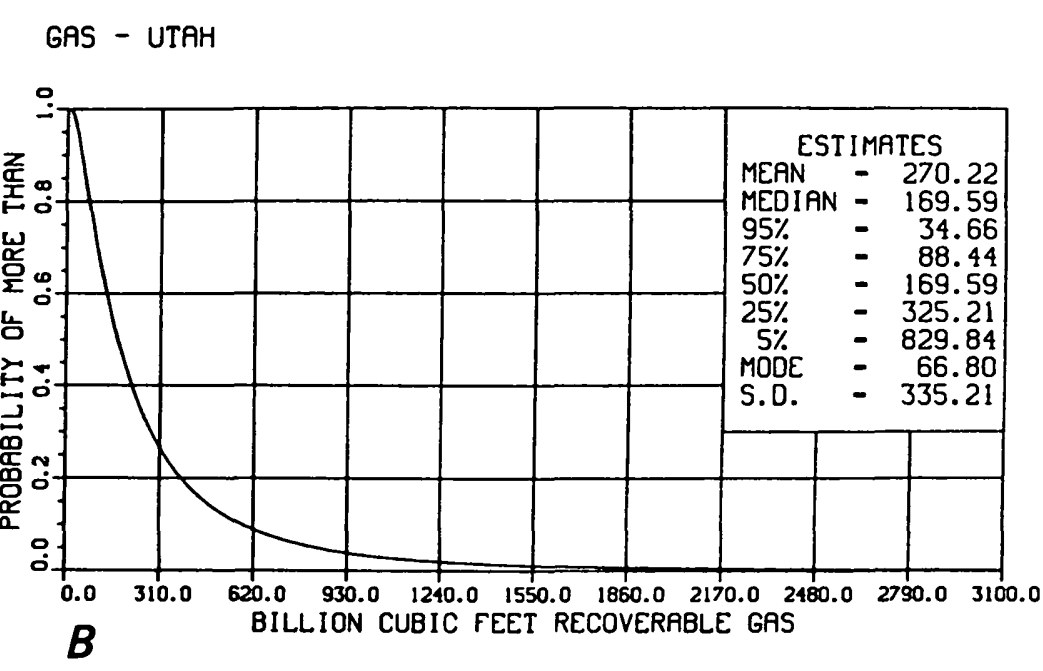

FIGURE 10B.-Undiscovered recoverable gas resources in Wilderness Lands in Utah.

$$
\text { GAS - WASHINGTON }
$$

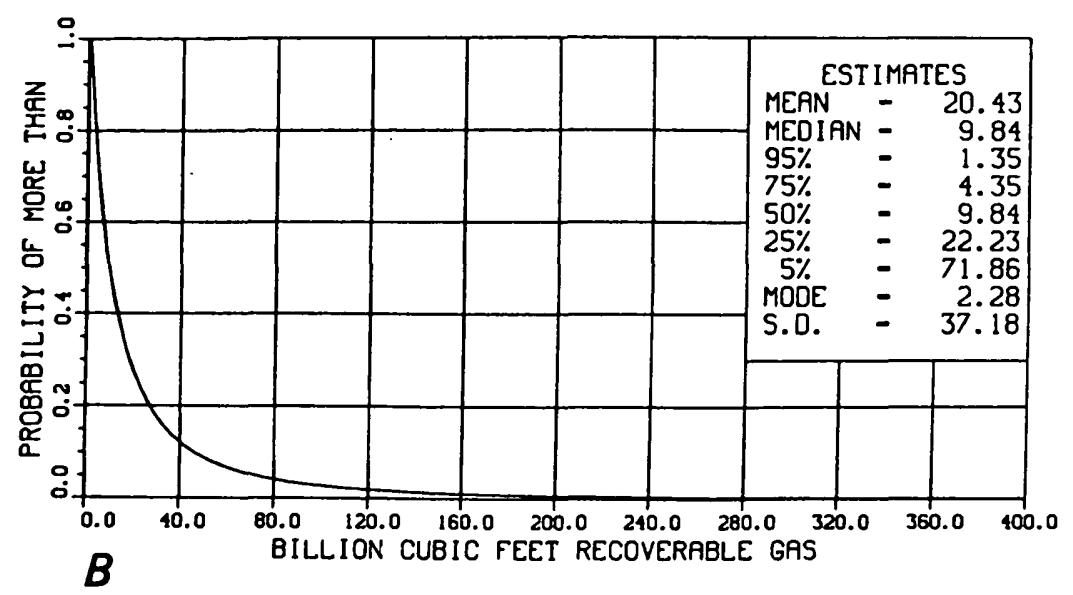

FIGURE 11B.-Undiscovered recoverable gas resources in Wilderness Lands in Washington. 
OIL - WYOMING

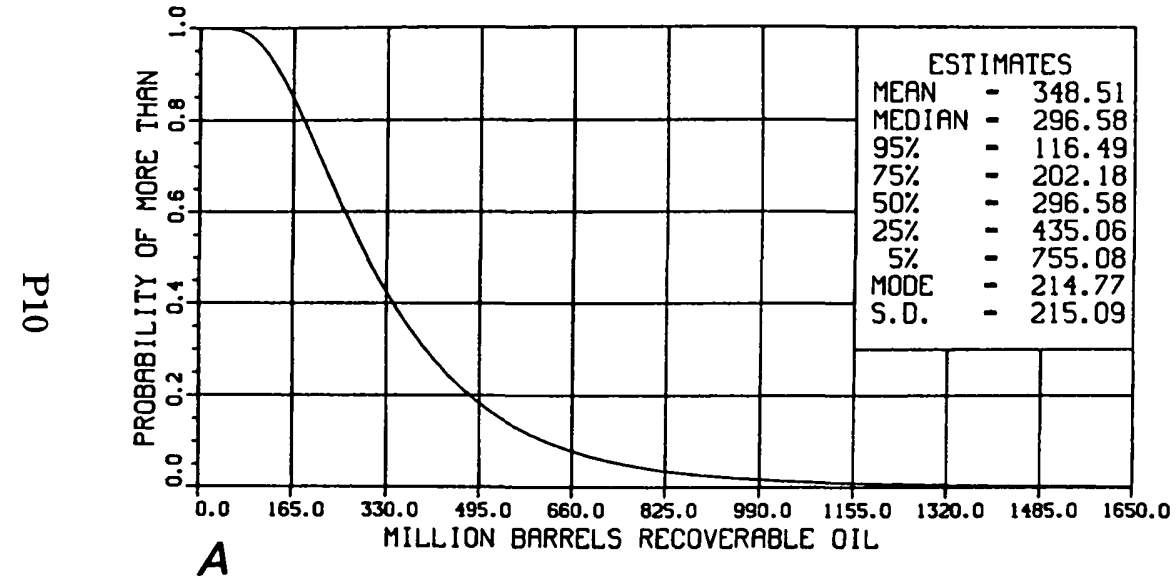

Figure 12A.-Undiscovered recoverable oil resources in Wilderness Lands in Wyoming.
GAS - WYOMING

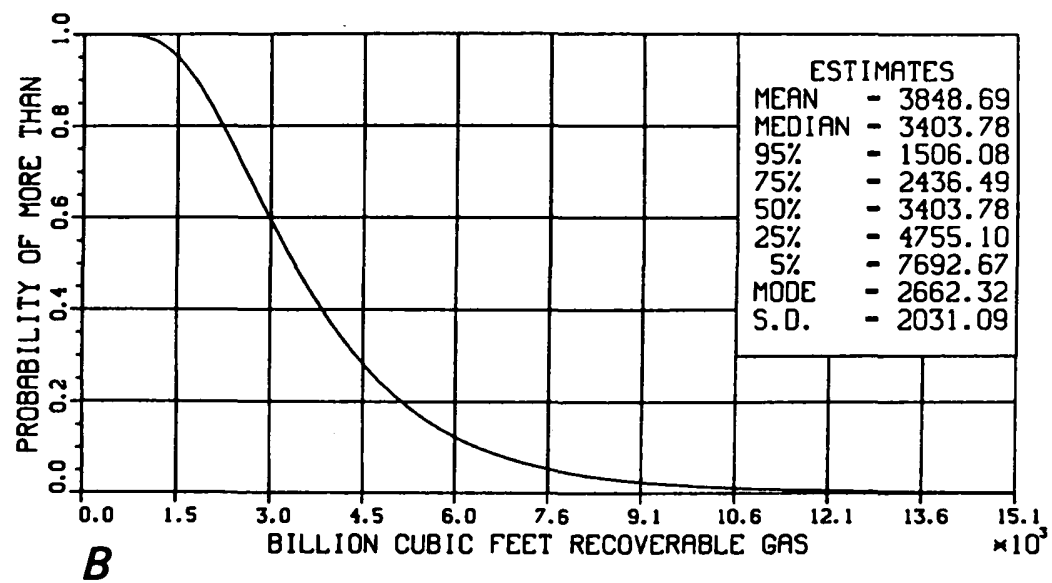

Figure 12B.-Undiscovered recoverable gas resources in Wilderness Lands in Wyoming. 
OIL - 11 WESTERN STATES

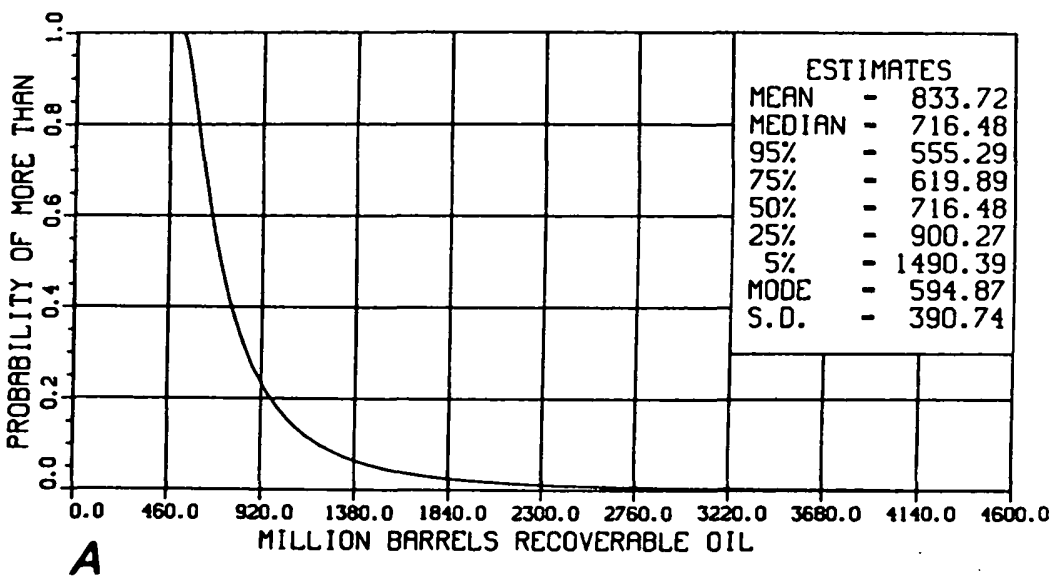

FIGURE 13A.-Total undiscovered recoverable oil resources in Wilderness Lands in 11 Western States.

OIL

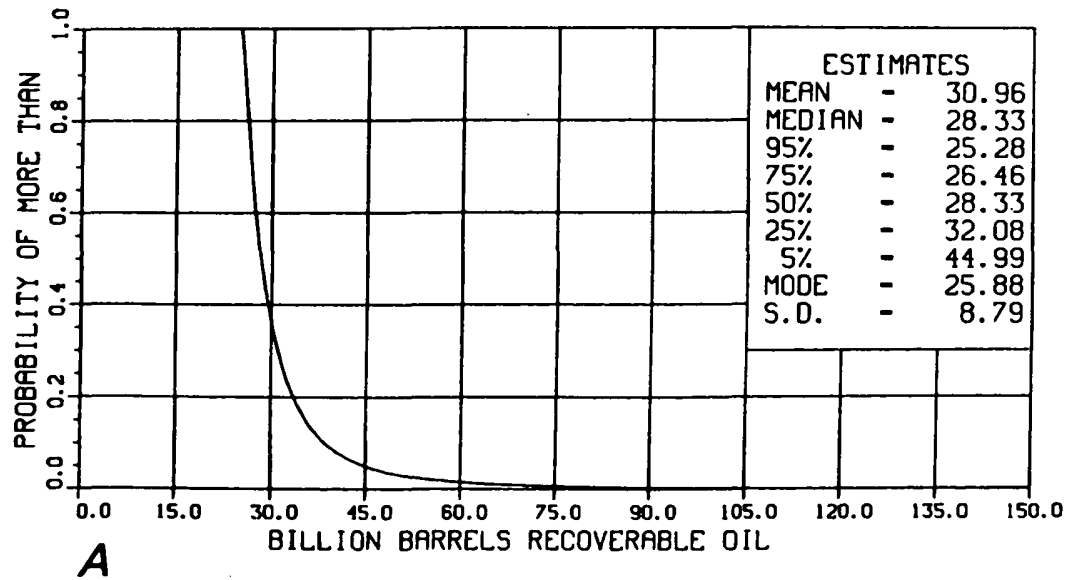

FIGURE 14A.-Total undiscovered recoverable oil resources in the 38 USGS western petroleum provinces in which Wilderness Lands are located that were included in this study (Dolton and others, 1981).
GAS - 11 WESTERN STATES

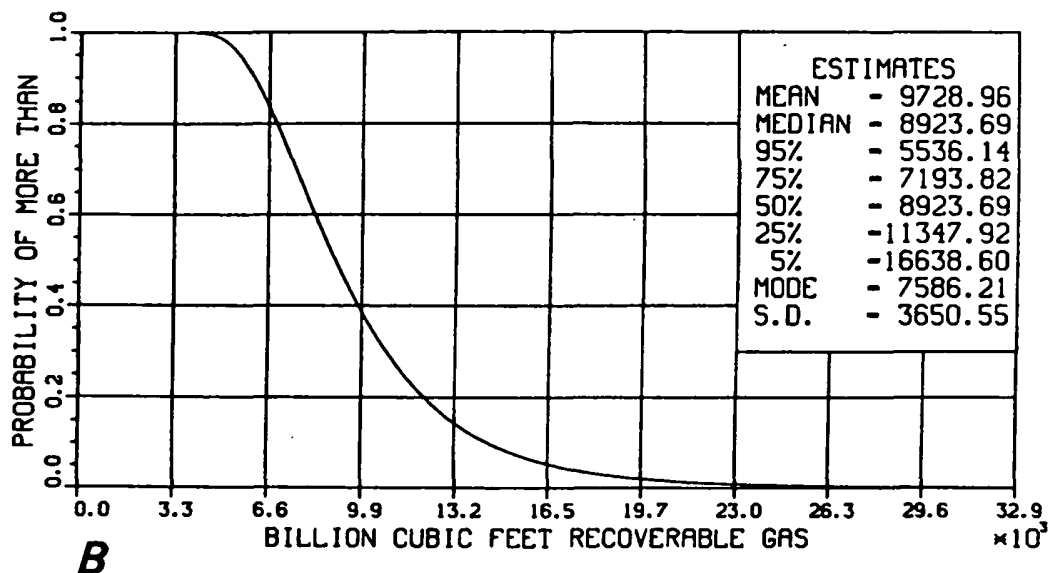

FIGURE 13B.-Total undiscovered recoverable gas resources in Wilderness Lands in 11 Western States.

GAS

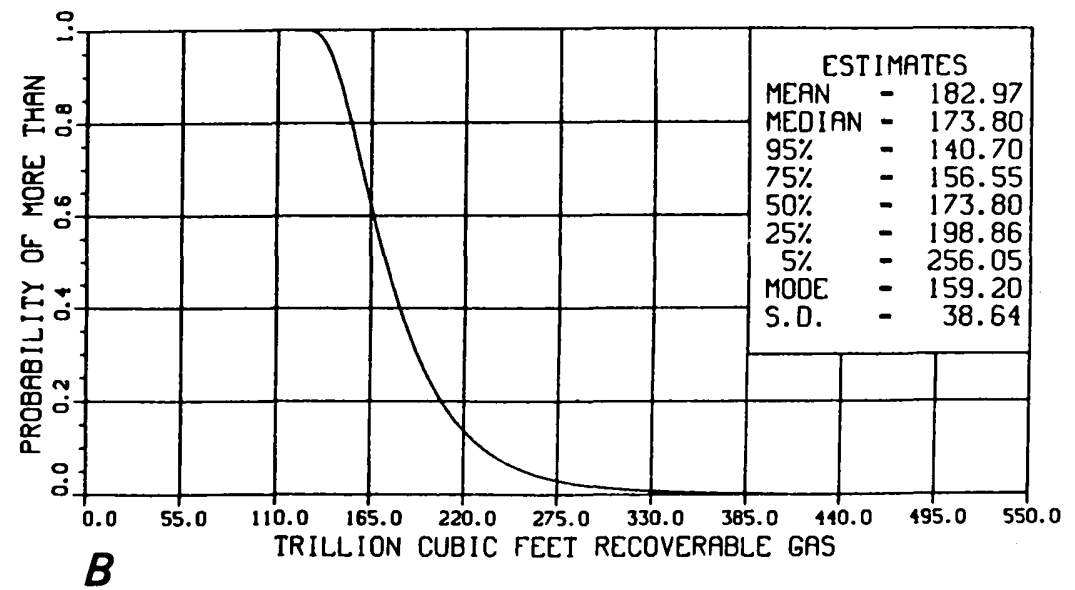

FIGURE 14B.-Total undiscovered recoverable gas resources in the 38 USGS western petroleum provinces in which Wilderness Lands are located that were included in this study (Dolton and others, 1981). 
TABLE 3.-Petroleum potential in Wilderness Lands by State in Western United States

[Acreage expressed in thousands of acres]

\begin{tabular}{|c|c|c|c|c|c|c|c|c|}
\hline \multirow[b]{2}{*}{ State } & \multicolumn{3}{|c|}{$\begin{array}{l}\text { Undiscovered recoverable oil }{ }^{1} \\
\text { (million barrels) }\end{array}$} & \multicolumn{3}{|c|}{$\begin{array}{l}\text { Undiscovered recoverable gas } \\
\text { (billion cubic feet) }\end{array}$} & \multirow{2}{*}{$\begin{array}{c}\text { Total acres } \\
\text { assessed } \\
\text { with } \\
\text { potential }^{3}\end{array}$} & \multirow{2}{*}{$\begin{array}{c}\text { Total acres } \\
\text { of } \\
\text { Wilderness } \\
\text { Lands in } \\
\text { State }\end{array}$} \\
\hline & $\begin{array}{l}\text { Low }^{2} \\
\mathrm{~F}_{95}\end{array}$ & $\begin{array}{l}\text { High } \\
\mathrm{F}_{5}\end{array}$ & Mean & $\begin{array}{l}\text { Low } \\
F_{\text {gs }}\end{array}$ & $\begin{array}{l}\text { High } \\
F_{s}\end{array}$ & Mean & & \\
\hline Arizona & 0.06 & 11.24 & 2.91 & 0.16 & 31.37 & 8.11 & $5,096.0$ & $6,183.8$ \\
\hline California & 2.69 & 30.12 & 11.60 & 1.37 & 13.64 & 5.37 & $11,596.0$ & $18,848.6$ \\
\hline Colorado & 3.20 & 25.54 & 9.16 & 31.11 & 320.16 & 128.28 & $1,054.4$ & $4,501.1$ \\
\hline Idaho & 77.56 & 427.38 & 206.79 & 850.15 & $3,351.45$ & $1,841.25$ & $2,006.9$ & $7,559.2$ \\
\hline Montana & 1.70 & 105.98 & 29.55 & 623.86 & $8,049.33$ & $3,031.33$ & $5,067.1$ & $6,930.7$ \\
\hline Nevada & 3.03 & 349.21 & 92.11 & 16.28 & $1,423.76$ & 383.35 & $4,862.7$ & $7,980.6$ \\
\hline New Mexico & 2.43 & 20.16 & 7.59 & 52.67 & 273.92 & 122.13 & $1,607.2$ & $2,676.8$ \\
\hline Oregon & .04 & 13.19 & 3.42 & 5.01 & 242.25 & 69.80 & $4,865.8$ & $4,865.8$ \\
\hline Utah & 12.45 & 391.14 & 120.83 & 34.66 & 829.84 & 270.22 & $3,857.6$ & $4,482.8$ \\
\hline Washington & .03 & 4.74 & 1.24 & 1.35 & 71.86 & 20.43 & $3,892.9$ & $3,892.9$ \\
\hline Wyoming & 116.49 & 755.08 & 348.51 & $1,506.08$ & $7,692.67$ & $3,848.69$ & $1,795.9$ & $6,007.0$ \\
\hline Total & 555.29 & $1,490.39$ & 833.71 & $5,536.14$ & $16,638.60$ & $9,728.96$ & $45,701.5$ & $73,928.3$ \\
\hline
\end{tabular}

\footnotetext{
'The marginal probabilities of a resource for the wilderness clusters were applied to the corresponding conditional probability distribution of the quantity of undiscovered recoverable resource. These distributions, used in this report, are referred to as the "unconditional" or "risked" distribution.

${ }^{\prime} F_{p s}$ denotes the 95 th fractile; the probability of more than the amount $F_{28}$ is 95 percent. $F_{s}$ is defined similarly. Fractile values are not additive.

The total acres of Wilderness Lands assessed with potential for each of the States include those lands assigned a high, medium, low, and low to zero potential. The Wil. derness Lands not included in the quantitative assessment procedures are those assigned a zero potential or an unknown potential.
}

The percentage estimates of the amounts of petroleum resources within the Wilderness Lands of the 11 Western States relative to the total provinces is a conservative estimate. This is due to the fact that major portions of four of the petroleum provinces extend beyond the eastern boundary of the 11-State study area and three of the four are major petroleum producing provinces: the Williston Basin, the Denver Basin, and the Permian Basin. A more accurate calculation of the percent of the resources in the Wilderness Lands of the 11 Western States relative to the total resources of these States would require the subtraction from the total of those resources in the four provinces which extend eastward beyond the study area boundaries and outside the 11-State area.

To put these comparative estimates into perspective, it is essential to consider the distribution of the sizes of the wilderness tracts within the Western States relative to the distribution of the Wilderness Lands which fall within prospectively favorable sedimentary provinces versus those Wilderness Lands that occur within unfavorable igneous and metamorphic terranes, or those Wilderness Lands which fall within geologic terranes that are either considered to have zero potential or are unknown in their petroleum potential. Table 4 summarizes some of these statistical re- lationships relative to the distribution and size of the wilderness tracts.

The minimum- to the maximum-sized wilderness tract ranges from 4 acres in California to 2.5 million acres in Idaho. The average tract size for the 1,636 digitized wilderness polygons is 45 thousand acres or approximately 70 square miles. These relationships are pertinent to the issue of speculating on the probable field size distributions that may occur within any of the wilderness tracts. At the present time there is not sufficient geologic data on any of the petroleum prospective wilderness tracts to make credible estimates of the field sizes likely to occur within these lands. It is important to note, however, that the bulk of petroleum resources in most sedimentary basins is likely to be concentrated in a relatively few larger fields. It is conceivable that a number of the prospective wilderness tracts could support the occurrence of some significant oil and gas fields. It is also highly unlikely that oil and gas fields of any significant size would occur in some of the very small wilderness tracts. The two smallest wilderness tracts recorded were in California at 4 and 9 acres respectively. The largest wilderness tract recorded was in Idaho at 2.5 million acres, or 3,906 square miles with zero petroleum potential due to location over the Idaho batholith. 
TABLE 4.-Statistics on the distribution of Wilderness Lands in the Western United States

[Acreage expressed in thousands of acres]

\begin{tabular}{|c|c|c|c|c|c|c|c|c|}
\hline State & $\begin{array}{l}\text { Number of } \\
\text { wilderness } \\
\text { polygons }\end{array}$ & $\begin{array}{l}\text { Minimum- } \\
\text { sized tract } \\
\text { recorded }\end{array}$ & $\begin{array}{l}\text { Maximum- } \\
\text { sized tract } \\
\text { recorded }\end{array}$ & $\begin{array}{l}\text { Average } \\
\text { tract size }\end{array}$ & $\begin{array}{c}\text { Total acreage } \\
\text { with } \\
\text { petroleum } \\
\text { potential }\end{array}$ & $\begin{array}{l}\text { Total acreage } \\
\text { with low to } \\
\text { zero and } \\
\text { unknown } \\
\text { potential }\end{array}$ & $\begin{array}{c}\text { Total acres } \\
\text { with zero } \\
\text { petroleum } \\
\text { potential }\end{array}$ & $\begin{array}{c}\text { Total acreage } \\
\text { Wilderness } \\
\text { Lands }\end{array}$ \\
\hline Arizona & 164 & 0.185 & 517.6 & 37.7 & $1,567.2$ & $3,528.8$ & $1,087.8$ & $6,183.8$ \\
\hline California & 511 & .004 & 699.3 & 36.9 & $1,346.7$ & $10,249.3$ & $7,252.6$ & $18,848.6$ \\
\hline Colorado & 122 & .183 & 170.0 & 36.9 & $1,054.4$ & $1,001.4$ & $2,445.3$ & $4,501.1$ \\
\hline Idaho & 94 & .178 & $2,465.8$ & 80.4 & 983.2 & $1,060.4$ & $5,515.6$ & $7,559.2$ \\
\hline Montana & 150 & .072 & $1,543.6$ & 46.2 & $3,854.9$ & $1,250.4$ & $1,825.4$ & $6,930.7$ \\
\hline Nevada & 136 & .540 & 416.9 & 58.7 & $4,862.7$ & 0 & $3,117.9$ & $7,980.6$ \\
\hline New Mexico & 82 & .233 & 545.1 & 32.6 & $1,449.2$ & 158.0 & $1,069.6$ & $2,676.8$ \\
\hline Oregon & 114 & .120 & 513.8 & 42.7 & $3,007.9$ & $1,857.9$ & 0 & $4,865.8$ \\
\hline Utah & 129 & .189 & 477.8 & 34.8 & $3,857.6$ & 0 & 625.2 & $4,482.8$ \\
\hline Washington & 42 & 2.393 & 843.9 & 92.7 & 952.4 & $2,940.5$ & 0 & $3,892.9$ \\
\hline Wyoming & 92 & .150 & 664.2 & 65.3 & $1,776.9$ & $2,470.8$ & $1,759.3$ & $6,007.0$ \\
\hline Total & 1,636 & .004 & $2,465.8$ & 45.2 & $24,713.1$ & $24,517.5$ & $24,698.7$ & $73,928.3^{2}$ \\
\hline
\end{tabular}

'The number of wilderness polygons is the number of individual closed plane figures (or tracts) which were digitized from the land status maps and calculated for acreage. This number is equal to or greater than the actual number of legally identified wilderness tracts. Many of the Wilderness Lands were digitized in separate pieces when the wilderness area was broken up by streams and other mapped discontinuities.

'All tabulated values for total acreage are rounded numbers; therefore, values may not be precise beyond decimal.

Additional geologic and geophysical data that may be available in the future and (or) any signifcant oil or gas field discoveries relative to the location of the Wilderness Lands would require a reevalaution of the oil and gas resource estimates to stay current with the state of geologic knowledge in these areas.

\section{SUMMARY}

In 1982-83, the U.S. Geological Survey (USGS) conducted an investigation of the oil and gas potential of the designated and proposed Wilderness Lands in the Western United States. This undertaking was in response to the national concerns in the last few years over sources for continuing energy supplies which centered around the issue of the probable occurrence of energy and nonenergy minerals on Federal lands. In particular, the most controversial issues have been focused upon the potential of the Nation's Wilderness Lands.

In this ongoing effort to access the petroleum potential on all Federal lands, the scope of this study is limited to the conventional recoverable petroleum resources occurring in the designated and proposed Wilderness Lands of the Western United States. This includes the Wilderness Lands administered under four Federal agencies: Bureau of Land Management (BLM), U.S. Forest
Service (USFS), National Park Service (NPS), and Fish and Wildlife Service (FWS).

The total area of the study includes approximately 74 million acres of Wilderness Lands in these 11 Western States: Arizona, California, Colorado, Idaho, Montana, Nevada, New Mexico, Oregon, Utah, Washington, and Wyoming. The 74 million acres represent 31 percent of the total Federal lands within these 11 Western States. Approximately 49 percent of all the lands in these States are federally owned.

The objective of this study is to assemble through various means all the available pertinent information that can be brought together within the USGS and integrate these data into a computer-based digital cartographic data system that is focused upon the single issue of reviewing the known geological and geophysical data to determine the geologic characteristics favorable or unfavorable for the occurrence of petroleum resources in these Wilderness Lands. In a joint effort in the USGS between the Geologic Division (GD) and the National Mapping Division (NMD) all of the mappable information used in this study was prepared and processed by using digital cartographic techniques. These include digitizing the location and boundaries of the Wilderness Lands; acreage calculations; the boundaries of the USGS petroleum provinces; and the geologic and tectonic 
boundaries within each petroleum province and State. In addition, searches were conducted on well data files which provided the locations and geologic information on over 5,000 wells drilled within or immediately adjacent to the Wilderness Lands.

An analysis of all the geologic characteristics favorable or unfavorable for petroleum occurrence in conjunction with the geologic settings for the Wilderness Lands scattered within the framework of the petroleum provinces was performed by a team of geologists on each of the wilderness tracts. The geologic characteristics reviewed for each tract included the presence or absence of the following: adequate source beds and reservoir rocks; adequate trapping mechanisms; favorable thermal and maturation histories; presence of petroleum seeps or adjacent wells with shows or production; and the presence of favorable sedimentary rock sections underlying volcanic terrane or faulted and overthrust areas.

A description of the geology and geologic framework is provided for each State along with an explanation of the interpretative geology and evaluation of the petroleum potential within the locale of each of the wilderness tracts.

The assessment of the petroleum resources on the Wilderness Lands was completed in two separate stages. In the first stage the geologists evaluated the geological characteristics for the favorability or lack of favorability for the occurrence of oil and natural gas within each wilderness tract and assigned a qualitative rating for each tract's potential for the occurrence of recoverable oil and gas resources. In the second stage in evaluating the petroleum potential for the wilderness tracts, an effort was made to arrive at a quantitative assessment within the framework of the USGS's latest published resource estimates which are made on a province basis (Dolton and others, 1981). The geologic characteristics evaluated for the favorability of petroleum occurrence within each of the clusters of wilderness tracts were the determining factors for the subjective assessments of the petroleum potential for each wilderness tract occurring within the respective basin or province. The quantitative resource assessments are subjectively determined as to the richness and potential of the wilderness tracts relative to the total petroleum potential for the respective petroleum province within which they occur.
The results of the qualitative analysis of the petroleum potential of the Wilderness Lands are tabulated by total acreages for each wilderness tract as classified by its potential rating. These tabulations are made for the Wilderness Lands by petroleum province, by State, and for the total Wilderness Lands in the 11 Western States. A summary is provided of the petroleum potential by acreage for all the Wilderness Lands in the Western United States by State and for the total 11 States. At least 34 percent of the total acreage for Wilderness Lands, or approximately 25 million acres, may have the geologic characteristics necessary for the occurrence of petroleum resources in varying amounts (high, medium, and low potential). An additional 33 percent of the Wilderness Lands may have some limited potential where small sedimentary areas are mixed within igneous and metamorphic terrane, but are more likely to fall in the low to zero potential. Finally, 33 percent of the Wilderness Lands probably have no petroleum potential because they are located in terranes with predominantly igneous and (or) metamorphic rocks in which petroleum has rarely been found.

The quantitative petroleum assessments for the Wilderness Lands in the Western United States represent a part of the total estimate of the remaining undiscovered oil and natural gas for the 38 petroleum provinces within which the Wilderness Lands occur, as defined by Dolton and others in USGS Circular 860 in 1981. The undiscovered recoverable oil for the Wilderness Lands in the Western States is estimated to range from more than 0.555 to 1.490 billion barrels with a mean estimate of 0.834 billion barrels. The undiscovered recoverable natural gas is estimated to range from more than $\mathbf{5 . 5 3 6}$ to $\mathbf{1 6 . 6 3 9}$ trillion cubic feet with a mean estimate of 9.729 trillion cubic feet. Each range corresponds to the 95 and 5 percent probabilities of more than the respective amounts. The oil and gas resource estimates reported at the 95 percent and 5 percent probabilities and the mean estimates are summarized for the separate States and the aggregated totals.

For comparative purposes the total undiscovered recoverable oil and gas resources estimated for the 38 petroleum provinces in the Western United States were aggregated from Dolton and others (1981) to provide probability distributions for the total oil and gas resource amounts for those western provinces in which the 74 million 
acres of Wilderness Lands are located in this study. An estimated percentage range of the amounts of undiscovered recoverable petroleum resources within these 38 petroleum provinces which may occur within the' designated and proposed Wilderness Lands for the Western States are more than 2.2 percent to 3.3 percent of the total oil resource, and more than 3.9 percent to 6.5 percent of the total natural gas resource, reported at the 95 percent and 5 percent probability range.

A series of printed maps, one for each Western State, accompanies this report (USGS Miscellaneous Investigations Series Maps I-1537-I-1547, in press) and show in color the location and qualitative petroleum potential of the Wilderness Lands studied, with BLM identification of wilderness tracts; the boundary locations of all major Federal and Indian lands; the boundaries and identification of the USGS petroleum provinces; and other base information. A pamphlet accompanies each State map describing the geology of the State and the local geology relative to the position of the wilderness tracts and their petroleum potential. These maps were compiled by using traditional cartographic techniques from digitally produced graphics and are published as separate sheets for each State at a scale of $1: 1,000,000$.

\section{REFERENCE CITED}

Dolton, G. L., Carlson, K. H., Charpentier, R. R., Coury, A. B., Crovelli, R.A., Frezon, S. E., Khan, A. S., Lister, J. H., McMullin, R. H., Pike, R. S., Powers, R. B., Scott, E. W., and Varnes, K. L., 1981, Estimates of undiscovered recoverable conventional resources of oil and gas in the United States: U.S. Geological Survey Circular 860, 87 p. 


\title{
CONCLUSIONS
}

\author{
By Betty M. Miller
}

The purpose of this study was twofold: (1) to assemble through various means all the available pertinent information within the USGS which focused upon the single issue of reviewing the geological and geophysical data to determine the geologic characteristics favorable or unfavorable for the occurrence of petroleum resources in 74 million acres of Wilderness Lands in the Western United States and (2) to estimate the potential petroleum resources that may occur within these Wilderness Lands both by qualitative assessment rating procedures and by estimating the quantities of conventional recoverable oil and natural gas that may occur within these lands by using subjective probability procedures.

The complexity of multiple data sources which are essential to the assessment of petroleum potential in the Wilderness Lands scattered across the vast expanse of the Western United States can be rapidly compiled, relatively speaking, and integrated into a multivariate data system by applying digital cartographic techniques. By applying these digital techniques, the lead-time for data compilation and assimilation for such a large undertaking can be significantly reduced which allows the geologists to proceed more rapidly to the analysis, evaluation, and assessment stages of the project. The integration of the basic data by computerized systems and digital cartographic technology also provides a vehicle in which the intermediate results derived during the study can be incorporated into the computerized system, tabulated, and summarized for the final results. Thus the digital cartographic data are easily updated, rapidly processed, and provide a rapid and flexible means of preparing final data tabulations and machine-produced map products.

The USGS Miscellaneous Investigations Series Maps showing the petroleum potential for the Wilderness Lands in the 11 Western States, a product of the qualitative analysis, provide a unique and use- ful set of maps at a scale of 1:1,000,000 (I-1537I-1547, in press). The locations and identification of the administrating agencies of the designated and proposed Wilderness Lands shown on the State maps along with their respective potential for the occurrence of petroleum resources and the boundaries of the petroleum provinces provide a perspective for the users of these maps relative to the probable resource potential of these Federal lands.

Those lands with reported high, medium, and low petroleum potential usually occur in areas possessing sedimentary geological characteristics, whereas those with low to zero and zero potential range from mixed sedimentary to metamorphic and igneous or volcanic terranes. However, areas of low to zero petroleum potential may be highly favorable for mineral potential, or in some instances areas in which other unconventional organic resources such as oil shales, tight gas sands, and coal deposits occur. Energy and mineral commodities other than conventional recoverable oil and natural gas were not included in this study. At least 34 percent of the total acreage in Wilderness Lands, approximately 25 million acres, may have the geologic characteristics necessary for the occurrence of petroleum resources in varying amounts of high, medium, and low potential. An additional 33 percent of the Wilderness Lands may have some limited potential, but is more likely to fall in the low to zero potential and in the unknown categories. Finally, 33 percent of the Wilderness Lands probably have no potential petroleum because they are located in terranes with predominantly igneous and (or) metamorphic rocks in which petroleum has rarely been found.

The quantitative assessments of the petroleum potential in Wilderness Lands are based upon the results of procedures which the geologists have sequentially followed from the input in the qualitative assessments to the subjective estimates 
which provide the output as probability distributions reported for the quantitative estimates. The quantitative resource assessments are subjectively determined as to the richness and potential of the wilderness tracts relative to the total petroleum potential for the respective petroleum province within which they occur. These risked estimates are reported as probability distributions with minimum and maximum estimated amounts of conventional undiscovered recoverable oil and gas resources reported at the 95 percent and 5 percent probability levels.

The undiscovered recoverable oil for the total Wilderness Lands in the Western States based upon currently available information is estimated to range from more than 0.555 to 1.490 billion barrels with a mean estimate of 0.834 billion barrels.
The undiscovered recoverable natural gas is estimated to range from more than 5.536 to 16.639 trillion cubic feet with a mean estimate of 9.729 trillion cubic feet. These assessments should be viewed in light of the currently available and often limited geologic information which is frequently interpreted with a high degree of uncertainty where subsurface information is unavailable due to no exploratory drilling within many of the areas.

Additional geologic and geophysical data that may be available in the future and (or) any significant oil or gas field discoveries relative to the location of the Wilderness Lands would require a reevaluation of the oil and gas resource estimates to stay current with the state of geologic knowledge in these areas. 


\section{RESOURCE APPRAISAL GROUP (RAG) PETROLEUM PROVINCES BY NUMBER, NAME, AND STATES IN WHICH WILDERNESS LANDS OCCUR FOR WESTERN UNITED STATES1}

\begin{tabular}{|c|c|c|}
\hline & $\begin{array}{l}\text { Regions and provinces } \\
\text { Number and name }\end{array}$ & $\begin{array}{l}\text { States in which } \\
\text { Wilderness Lands occur }\end{array}$ \\
\hline \multicolumn{3}{|c|}{ Pacific Coast } \\
\hline 72 & Western Oregon-Washington & Oregon and Washington \\
\hline 73 & Sacramento Basin & California \\
\hline 74 & San Joaquin Basin & California \\
\hline 75 & Los Angeles Basin & California \\
\hline 76 & Ventura Basin & California \\
\hline 77 & Santa Maria Basin & California \\
\hline 78 & Central Coastal Basins & California \\
\hline 79 & Sonoma-Livermore Basins & California \\
\hline 80 & Humboldt Basin & California \\
\hline 81 & Eastern Oregon-Washington & Oregon and Washington \\
\hline $81 \mathrm{~A}$ & Eastern California & California \\
\hline \multicolumn{3}{|c|}{ Colorado Plateau and Basin and Range } \\
\hline 82 & Eastern Basin and Range & Utah, Nevada, and Idaho \\
\hline 83 & Western Basin and Range & Nevada \\
\hline 84 & Idaho-Snake River Downwarp & Idaho \\
\hline 85 & Paradox Basin & Utah and Colorado \\
\hline 86 & Uinta-Piceance-Eagle Basins & Utah and Colorado \\
\hline 87 & Park Basins & Colorado \\
\hline 88 & San Juan Basin & New Mexico and Colorado \\
\hline 89 & Albuquerque-Santa Fe-San Luis Rift Basins & New Mexico and Colorado \\
\hline 90 & Wyoming-Utah-Idaho Overthrust Belt & Wyoming, Utah, and Idaho \\
\hline 91 & Northern Arizona & Arizona \\
\hline 92 & South-central New Mexico & New Mexico \\
\hline 93 & Southern Arizona-Southwestern New Mexico & Arizona and New Mexico \\
\hline \multicolumn{3}{|c|}{ Rocky Mountains and Northern Great Plains } \\
\hline 94 & Williston Basin & Montana ${ }^{1}$ \\
\hline 96 & Sweetgrass Arch & Montana \\
\hline 97 & Central Montana & Montana \\
\hline 98 & Montana Overthrust Belt & Montana and Idaho \\
\hline 99 & Southwestern Montana & Montana \\
\hline 100 & Wind River Basin & Wyoming \\
\hline 101 & Powder River Basin & Montana and Wyoming \\
\hline 102 & Southwestern Wyoming Basins & Wyoming, Utah, Colorado, and Idaho \\
\hline 103 & Big Horn Basin & Wyoming and Montana \\
\hline 104 & Denver Basin & Colorado and Wyoming ${ }^{1}$ \\
\hline 105 & Las Animas Arch & Colorado $^{1}$ \\
\hline 106 & Raton Basin-Sierra Grande Uplift & Colorado and New Mexico \\
\hline \multicolumn{3}{|c|}{ West Texas and Eastern New Mexico } \\
\hline 107 & Permian Basin & New Mexico ${ }^{1}$ \\
\hline 108 & Palo Duro Basin & New Mexico ${ }^{1}$ \\
\hline 109 & Pedernal Uplift & New Mexico ${ }^{1}$ \\
\hline
\end{tabular}

'States not included are outside of study area. (Taken from Dolton and others, 1981.) 